\title{
PERBAIKA LINGKUNGAN KERJA GUNA MENINGKATKAN PRODUKTIVITAS DAN KESEJAHTERAAN PENGRAJIN ATAP DAUN NIPAH TRADISIONAL DI DESA PULAU PALAS DENGAN METODE WORK SAMPLING
}

\section{Randi Sofian}

Program Studi Teknik Industri, Universitas Islam Indragiri

Jln. Provinsi Parit 1 Tembilahan - Indragiri Hilir- Riau

Email : randisofian48@gmail.com

\begin{abstract}
Abstrak
Work productivity is the ability of employees to produce compared to the inputs used, an employee can be said to be productive if they are able to produce goods or services as expected in a short or appropriate time. Productivity is not a calculation of quantity, but a ratio, a comparison and a systematic measurement of a level of efficiency. Production is related to quantity, while productivity is related to the results of unity from an input (Sinungan, 1990: 93). Thus the determination of productivity is faced with the desired results achieved (effectiveness) and the resources used to achieve these results (efficiency). Measurements using measures of efficiency and effectiveness are two dimensions of productivity that are very important in managerial business where they can show productivity indexes which are the ratios to the extent to which resources are used in conjunction with achieving predetermined goals.

The results of the research are obtained from the productivity level of workers of palm leaf weavers using the side work method for two months, each study for 7 hours, namely coconut covering workers working productively with 95\% yield and delay ratio of $0.07 \%$, and allowance the nipah leaf weaver is $23.6 \%$ with the following details: $12.00 \%$ of energy released, $4.5 \%$ work attitude, $1.3 \%$ work movement, $0 \%$ eye fatigue, temperature condition the workplace is $5.50 \%$, the atmosphere is $0.5 \%$, and the environment is good at $2.50 \%$.
\end{abstract}

Keywords : Work Productivity, Work Sampling

\section{PENDAHULUAN}

Salah satu kekayaan bumi kabupaten Indragiri Hilir yaitu melimpahnya nipah (Nypa fruticans)yang tumbuh dipesisir sungai, Bahan baku dari pembuatan atap daun nipah ini sangat mudah didapat secara Cuma-Cuma dari alam diantaranya seperti daun nipah, pelepah kelapa, dan bamban (Donax canniformis). Sejak dulu para pengrajin atap daun nipah ini banyak tersebar di wilayah Kabupaten Indragiri Hilir ini, sampai sekarang pengrajin atap daun dari daun nipah ini makin kualahan untuk memenuhi permintaan pasar yang selalu ingin mendapatkan daun nipah ini untuk atap rumah, kandang ternak, gudang, dan sebagainya. Mereka memilih atap daun nipah ini karna 
harganya ekonomis dan cukup kuat digunakan sampai empat tahun, dan daun atap ini juga memberikan kenyamanan tersendiri yaitu bahannya yang ringan dan efek dari atap daun nipah ini memberikan udara yang dingin sehingga cocok untuk kandang ternak dan sebagainya.

Pekerjaan dalam membuat atap daun nipah ini dikerjakan setiap hari yaitu dari pukul 08.00 - 17.00 dan waktu untuk istirahat pada pukul 12.00 - 13.00 yang dikerjakan oleh mayoritas ibu-ibu karena pekerjaan membuat atap daun nipah ini sangat mudah. Rata-rata output dalam pengolahan atap daun nipah ini dapat menghasilkan 40-60 keping sehari.

Berdasarkan survey pendahuluan yaitu wawancara langsung pada ibu-ibu pengrajin atap daun nipah maka diperoleh informasi bahwa para pengrajin atap merasa lingkungan kerjanya panas karena tidak adanya pelindung untuk mereka bekerja dan kebosanan pada saat bekerjapun cukup tinggi karena tidak adanya bunyi-bunyian yang membuat mereka tidak jenuh dalam melaksanakan aktivitasnya.

Suhu udara dianggap nyaman bagi orang Indonesia ialah sekitar $24^{\circ} \mathrm{C}$ sampai $26^{\mathrm{O}} \mathrm{C}$ dan selisih suhu didalam dan diluar tidak boleh lebih dari $5^{0} \mathrm{C}$.Keseimbangan panas suhu tubuh manusia selalu dipertahankan hampir konstan/menetap oleh suatu pengaturan suhu tubuh manusia (Ngizuddin, 2015).Salah satu tantangan dalam mengelola sumberdaya manusia yang berkaitan dengan kebutuhan karyawan adalah bagaimana menciptakan kondisi lingkungan kerja yang dapat memuaskan berbagai kebutuhan karyawan (Ida Kristina 2012). Lingkungan kerja mempunyai pengaruh langsung terhadap karyawan dalam melaksakan proses produksi, pengaruh lingkungan yang nyaman dalam bekerja dan dapat meningkatkan output. Kebosanan kerja bukan saja memberikan dampak yang negatif bagi kinerja seseorang di perusahaan atau organisasi dalam hal produktivitas mereka, tetapi juga dapat menyebabkan berbagai dampak psikologis yang dapat mengganggu kesejahteraan jiwa individu tersebut.Dampak psikologis tersebut misalnya timbulnya rasa hampa dalam diri individu tersebut, meragukan kemampuan diri sendiri atau sebaliknya justru bersikap arogan karena merasa semua tugas dapat dikerjakan tanpa kesulitan, hilangnya motivasi kerja (Wasono 2015).

Dari beberapa defenisi diatas dapat disimpulkan bahwa lingkungan kerja adalah segala sesuatu yang ada disekitar para pekerja/karyawan yang dapat mempengaruhi kepuasan kerja karywan dalam melaksanakan pekerjaannya sehingga akan diperoleh hasil kerja yang maksimal, dimana dalam lingkungan kerja tersebut terdapat fasilitas kerja yang mendukung karyawan dalam penyelesaian tugas yang dibebankan kepada karyawan guna meningkatkan kerja karyawan dalam suatu perusahaan atau usaha lainnya.

Permasalahan produktifitas dan kesejahteraan pengrajin atap daun nipah ini, maka akan dilakukan perbaikan yang bertujuan untuk meningkatkan hasil pembuatan atap daun nipah dan cepat memenuhi permintaan pelanggan atap daun nipah ini karena permintaan pelanggan sering kali tidak dapat terpenuhi oleh pelaku usaha ini, maka dilakukan perbaikan system kerja dengan metode work sampling.

Berdasarkan Latar Belakang seperti yang diuraikan diatas, maka perumusan masalah ini adalah :

1. Bagaimanakah membuat lingkungan kerja supaya menjadi sejuk dan tidak panas?

2. Bagaimanakah cara mengurangi tingkat kebosanan pada saat membuat atap?

3. Bagaimana peningkatan produktivitas pekerja setelah dilakukan perbaikan lingkungan kerja ?

Manfaat penelitian menggambarkan bagian yang menjelaskan yang ingin diperoleh dari penelitian yang dilakukan, adapun tujuan tersebut adalah :

1. Bagi Peneliti

Diharapkan hasil penelitian ini dapat bermanfaat bagi pengembangan ilmu bagi peneliti, Khususnya di bidang ilmu Ergonomi.

2. Bagi UKM

Adanya Inovasi baru yang dapat membuat pekerja sejahtera dalam mengerjakan 
pekerjaannya, dan dapat lebih banyak menghasilkan atap.

3. Peneliti pihak lain

Penelitian ini diharapkan bermanfaat bagi pihak-pihak lain dalam melakukan studi ergonomi yang sejenis dengan kasus ini.

\section{METODOLOGI PENELITIAN}

Studi pendahuan dilakukan untuk mengetahui secara langsung mengenai informasi-informasi yang dibutuhkan untuk pengolahan data. Adapun beberapa metode yang dilakukan dalam studi pendahualuan, yaitu sebagai nerikut :

1. Tinjauan Pustaka

Tinjauan pustaka dilakukan untuk mengetahui informasi-informasi secara teoritis mengenai pokok permasalahan dan teori-teori pendukung yang digunakan penulis sebagai dasar pemikiran untuk membahas permasalahan yang ada.

\section{Orientasi}

Orientasi bertujuan untuk mengetahui dan mempelajari kegiatan yang ada pada objek selama penelitian.

3. Pengambilan Data

Pengambilan data ini diperlukan sebagai bahan yang akan diolah sesuai dengan tugas khusus (pokok bahasan) masingmasing.

4. Konsultasi dan Diskusi

Konsultasi ini dapat dilakukan dengan dosen pembimbing dan pembimbing lapangan ditempat melakukan penelitian. Sedangkan diskusi dapat dilakukan dengan para pekerja dilapangan dan teman-teman sesama yang meneliti pada tugas akhir. Kegiatan ini akan memberikan masukan yang sangat berguna untuk menyelesaikan dan menyempurnakan laporan tugas akhir.

\section{Perumusan Masalah}

Tujuan dari perumusan masalah adalah untuk memperjelas tentang masalah yang akan diteliti dan dibahas. Adapun yang menjadi rumusan masalah dalam penelitian ini adalah sebagai berikut :

1. Bagaimanakah membuat lingkungan kerja supaya menjadi sejuk dan tidak panas?

2. Bagaimanakah cara mengurangi tingkat kebosanan pada saat membuat atap?

3. Bagaimana peningkatan produktivitas pekerja setelah dilakukan perbaikan lingkungan kerja?

\section{Pengumpulan Data}

Teknik pengumpulan data ini dibagi menjadi 2 bagian, yaitu :

1. Observasi

Observasi adalah proses pengamatan dan pencatatan secara sistematis mengenai gejalagejala yang diteliti. Observasi ini menjadi salah satu dari teknik pengumpulan data apabila sesuai dengan tujuan penelitian, yang ditencanakan dan dicatat secara sistematis mengenai tingkah laku dengan melihat atau mengamati individu atau kelompok secara langsung serta dapat dikontrol keandalannya (reliabilitas) dan kesahihannya (validitasnya).

\section{Dokumentasi}

Merupakan pengumpulan data yang berbentuk dokumen atau data hasil pengamatan yang dilakukan dan dijadikan sebuah dokumen. Dokumentasi yang peneliti lakukan yaitu berupa foto-foto pada saat pekerja sedang menganyam atau daun nipah.

\section{Pengolahan Data}

Pengolahan data ini dengan menggunakan metode Work Sampling yang diuraikan menjadi 6 tahapan Work Sampling, yaitu sebagai berikut :

1. Persentase kegiatan produktif

Yang dimaksud dengan persentase produktif adalah menjumlahkan beberapa hasil dari pengmatam dan dibagi dengan jumlah pengamatan.

2. Pemakaian peta kontrol dalam sampling kerja

Yang dimaksud pemakaian peta kontol adalah ketika pi berada dalam batas-batas ini,sehingga semua data dapat digunakan untuk 
menghitung banyaknya pengamatan yang diperlukan.

3. Uji kengumpulan data

Uji kecukupan data yang dimaksud adalah apabila $\mathrm{N}^{\prime}<\mathrm{N}$ maka suatu data dikatakan cukup, namun jika $\mathrm{N}^{\prime}>\mathrm{N}$ maka suatudata dikatakan kurang.

\section{Ratio delay}

Digunakan untuk mengetahui kinerja operator dalam melakukan suatu pekerjaan, berapa banyak waktu kerja operator tersebut dalam keadaan menganggur (idle).

5. Menghitung waktu baku

Waktu penyelesaian yang dibutuhkan secara wajar oleh pekerja normal untuk menyelesaikan pekerjaannya yang dikerjakan dalam sistem kerja terbaik pada saat itu.

\section{Faktor kelonggaran}

Kelonggaran diberikan untuk tiga hal yaitu untuk kebutuhan pribadi, menghilangkan rasa fatique, dan hambatan-hambatan yang tidak dapat dihindarkan. Ketiganya ini merupakan hal yang secara nyata dibutuhkan oleh pekerja, dan yang selam pengukuran tidak diamati, diukur, dicatat, ataupun dihitung.

\section{HASIL DAN PEMBAHASAN 4.1 Pengumpulan Data}

Proses pengumpulan data Sampling Kerja (Work Sampling) penganyam atap daun nipah di desa pulau palas keamatan tembilahan hulu Kabupaten Indragiri Hilir, yaitu melakukan pengamatan secara langsung selam ke pekerja penganyam atap daun nipah yang bertujuan untuk mendapatkan data sampling kerja (work sampling) pekerja penyungkil kelapa tersebut.

Selain dari itu, teknik dalam pengambilan data di usaha atap daun nipah ada dua bagian yaitu :

\section{Observasi}

Observasi adalah proses pengamatan dan pencatatan secara sistematis mengenai gejala-gejala yang diteliti. Observasi ini menjadi salah satu dari teknik pengumpulan data apabila sesuai dengan tujuan penelitian, yang ditencanakan dan dicatat secara sistematis mengenai tingkah laku dengan melihat atau mengamati individu atau kelompok secara langsung serta dapat dikontrol keandalannya (reliabilitas) dan kesahihannya (validitasnya).

\section{Dokumentasi}

Merupakan pengumpulan data yang berbentuk dokumen atau data hasil pengamatan yang dilakukan dan dijadikan sebuah dokumen. Dokumentasi yang peneliti lakukan yaitu berupa foto-foto saat pekerja penganyam atap sedang bekerja maupun sedang istirahat.

\section{Penentuan Jadwal Pengamatan}

Penentuan jadwal pengamatan bertujuan untuk mendapatkan waktu pengamatan secara random yang akan digunakan untuk mengetahui kegiatan yang dilakukan oleh pekerja. Pengamatan dilakukan mulai pukul 08:00 WIB sampai dengan pukul 12:00 WIB (istirahat pukul 12:00 - 13:00 WIB), kemudian pengamatan dilanjutkan pada puku 13:00 WIB sampai dengan jam 16:00

Dengan interval waкıu selama 11 dan 12 menit, penentuan jadwal pengamatan diperoleh melalui metode randomisasi yakni dengan menggunakan bantuan program excel.

Untuk menentukan banyaknya bilangan random yang diperlukan selama total waktu kerja penelitian dapat dilihat dari perhitungan berikut ini :

1. Untuk penelitian hari pertama dengan interval waktu 11 menit, dengan pengamatan dimulai dari pukul 08:00 WIB sampai dengan pukul 12:00 WIB (istirahat pukul 12:00 13:00 WIB), kemudian dilanjutkan lagi pada pukul 13:00 WIB sampai pukul 16:00 WIB, maka total waktu kerja adalah 7 jam kerja.

2. Untuk penelitian hari kedua dengan interval waktu 12 menit, dengan pengamatan dimulai dari pukul 08:00 WIB sampai dengan pukul 12:00 WIB (istirahat pukul 12:00 13:00 WIB), kemudian dilanjutkan lagi pada pukul 13:00 WIB sampai pukul 16:00 WIB, maka total waktu kerja adalah 7 jam kerja.

Maka satu hari kerja (7 jam) mempunyai 39 dan 35 satuan waktu pada dua hari penelitian. Ini berarti jumlah pengamatan perhari tidak boleh dari 39 dan 35 kali, hasil penyusunan waktu pengamatan berdasarkan interval waktu 11 dan 12 menit selama dua hari penelitian yang dilakukan. Dalam penelitian ini 
diambil 30 kali pengamatan pada hari pertama dan kedua pada penelitian yang peneliti lakukan dengan menggunakan metode randomisasi dengan bantuan excel untuk menentukan saat pengamatan tersebut.

Pada penelitian ini dilakukan kepada 1 orang pekerja dengan jenis kelamin wanita yang bekerja secara normal dan wajar yaitu bahwa pekerja dapat melaksanakan pekerjaan dengan cukup berpengalaman pada saat melakukan pekerjaan menyungkil kelapa tersebut, karena ini akan berpengaruh terhadap hasil dari penelitian tersebut.

Data pengambilan work sampling pada hari pertama akan dijelaskan pada tabel 4.1 sebagai berikut :

$\begin{array}{ll}\text { Objek Penelitian } & \text { : Penganyam atap } \\ \text { daun nipah } & \text { : Ratna } \\ \text { Nama Pekerja } & : 52 \text { Tahun } \\ \text { Umur } & : 8: 00-16: 00 \\ \text { Jam Pengamatan } & \end{array}$

Hari/Tanggal/Tahun : Selasa, 1 januari 2019

Angka Bilangan Random : : 11

Tabel 4.1 Data Pengamatan Work Sampling Pada Data masa lalu

\begin{tabular}{|c|c|c|c|c|c|}
\hline $\begin{array}{l}\text { N } \\
\text { o }\end{array}$ & $\begin{array}{l}\text { Bilanga } \\
\text { n Acak }\end{array}$ & $\begin{array}{l}\text { Jam } \\
\text { Kunjung } \\
\text { an }\end{array}$ & $\begin{array}{l}\text { Tally } \\
\text { Produkt } \\
\text { if }\end{array}$ & $\begin{array}{l}\text { Tall } \\
y \\
\text { Idle }\end{array}$ & $\begin{array}{l}\text { OI } \\
U\end{array}$ \\
\hline 1 & 2 & $8: 11$ & $\sqrt{ }$ & & 28 \\
\hline 2 & 3 & $8: 22$ & $\sqrt{ }$ & & 30 \\
\hline 3 & 4 & $8: 33$ & $\sqrt{ }$ & & 25 \\
\hline 4 & 6 & $8: 55$ & $\sqrt{ }$ & & 51 \\
\hline 5 & 7 & $9: 06$ & $\sqrt{ }$ & & 31 \\
\hline 6 & 9 & $9: 28$ & $\sqrt{ }$ & & 31 \\
\hline 7 & 10 & $9: 39$ & $\sqrt{ }$ & & 21 \\
\hline 8 & 11 & $9: 50$ & $\sqrt{ }$ & & 26 \\
\hline 9 & 12 & $10: 01$ & $\sqrt{ }$ & & 22 \\
\hline 10 & 14 & $10: 23$ & $\sqrt{ }$ & & 40 \\
\hline 11 & 15 & $10: 34$ & & $\sqrt{ }$ & - \\
\hline 12 & 17 & $10: 56$ & $\sqrt{ }$ & & 24 \\
\hline 13 & 19 & $11: 18$ & $\sqrt{ }$ & & 37 \\
\hline 14 & 20 & $11: 29$ & $\sqrt{ }$ & & 29 \\
\hline 15 & 21 & $11: 40$ & $\sqrt{ }$ & & 17 \\
\hline 16 & 22 & $11: 51$ & $\sqrt{ }$ & & 16 \\
\hline
\end{tabular}

\begin{tabular}{|c|c|c|c|c|c|}
\hline 17 & 24 & $13: 11$ & $\sqrt{ }$ & & 23 \\
\hline 18 & 27 & $13: 44$ & $\sqrt{ }$ & & 57 \\
\hline 19 & 28 & $13: 55$ & $\sqrt{ }$ & & 18 \\
\hline 20 & 29 & $14: 06$ & $\sqrt{ }$ & & 28 \\
\hline 21 & 30 & $14: 17$ & $\sqrt{ }$ & & 20 \\
\hline 22 & 31 & $14: 28$ & $\sqrt{ }$ & & 15 \\
\hline 23 & 32 & $14: 39$ & $\sqrt{ }$ & & 28 \\
\hline 24 & 33 & $14: 50$ & $\sqrt{ }$ & & 27 \\
\hline 25 & 34 & $15: 01$ & $\sqrt{ }$ & & 26 \\
\hline 26 & 35 & $15: 12$ & $\sqrt{ }$ & & 19 \\
\hline 27 & 36 & $15: 23$ & $\sqrt{ }$ & & 25 \\
\hline 28 & 37 & $15: 34$ & $\sqrt{ }$ & & 21 \\
\hline 29 & 38 & $15 ; 45$ & $\sqrt{ }$ & & 14 \\
\hline 30 & 39 & $15: 56$ & & $\sqrt{ }$ & - \\
\hline
\end{tabular}

Sumber : Pengumpulan Data

Data pengambilan work sampling pada bulan kedua akan dijelaskan pada tabel 4.2 sebagai berikut :

Objek Penelitian :Penganyam

Atap Daun Nipah

Nama Pekerja : Ratna

Umur

: 52 Tahun

Jam Pengamatan

:8:00-16:00 WIB

Hari/Tanggal/Tahun

:Rabu, 1 Februari

2019

Angka Bilangan Random : 12

Tabel 4.2 Data Pengamatan Work Sampling Pada Hari Kedua

\begin{tabular}{|c|c|c|c|c|c|}
\hline $\begin{array}{l}\text { N } \\
\text { o }\end{array}$ & $\begin{array}{l}\text { Bilanga } \\
\text { n Acak }\end{array}$ & $\begin{array}{l}\text { Jam } \\
\text { Kunjung } \\
\text { an }\end{array}$ & $\begin{array}{l}\text { Tally } \\
\text { Produkt } \\
\text { if }\end{array}$ & $\begin{array}{l}\text { Tall } \\
y \\
\text { Idle }\end{array}$ & $\begin{array}{l}\text { OI } \\
U\end{array}$ \\
\hline 1 & 2 & $8: 12$ & $\sqrt{ }$ & & 27 \\
\hline 2 & 3 & $8: 24$ & $\sqrt{ }$ & & 25 \\
\hline 3 & 4 & $8: 36$ & $\sqrt{ }$ & & 25 \\
\hline 4 & 5 & $8: 48$ & $\sqrt{ }$ & & 21 \\
\hline 5 & 7 & $9: 12$ & $\sqrt{ }$ & & 40 \\
\hline 6 & 8 & $9: 24$ & $\sqrt{ }$ & & 27 \\
\hline 7 & 9 & $9: 36$ & $\sqrt{ }$ & & 24 \\
\hline 8 & 10 & $9: 48$ & $\sqrt{ }$ & & 29 \\
\hline 9 & 11 & $10: 00$ & $\sqrt{ }$ & & 21 \\
\hline 10 & 13 & $10: 24$ & $\sqrt{ }$ & & 45 \\
\hline 11 & 14 & $10: 36$ & $\sqrt{ }$ & & 11 \\
\hline 12 & 15 & $10: 48$ & & $\sqrt{ }$ & - \\
\hline 13 & 16 & $11: 00$ & $\sqrt{ }$ & & 20 \\
\hline 14 & 17 & $11: 12$ & $\sqrt{ }$ & & 22 \\
\hline 15 & 18 & $11: 24$ & $\sqrt{ }$ & & 26 \\
\hline
\end{tabular}




\begin{tabular}{|l|l|l|l|l|l|}
\hline 16 & 19 & $11: 36$ & $\sqrt{ }$ & & 24 \\
\hline 17 & 20 & $11: 48$ & $\sqrt{ }$ & & 23 \\
\hline 18 & 22 & $13: 12$ & $\sqrt{ }$ & & 18 \\
\hline 19 & 23 & $13: 24$ & $\sqrt{ }$ & & 16 \\
\hline 20 & 24 & $14: 36$ & $\sqrt{ }$ & & 19 \\
\hline 21 & 25 & $14: 48$ & $\sqrt{ }$ & & 32 \\
\hline 22 & 26 & $14: 00$ & $\sqrt{ }$ & & 23 \\
\hline 23 & 27 & $14: 12$ & $\sqrt{ }$ & & 22 \\
\hline 24 & 28 & $14: 24$ & $\sqrt{ }$ & & 26 \\
\hline 25 & 29 & $14: 36$ & $\sqrt{ }$ & & 13 \\
\hline 26 & 31 & $15: 00$ & $\sqrt{ }$ & & 42 \\
\hline 27 & 32 & $15: 12$ & $\sqrt{ }$ & & 24 \\
\hline 28 & 33 & $15: 24$ & $\sqrt{ }$ & & 28 \\
\hline 29 & 34 & $15: 36$ & $\sqrt{ }$ & & 19 \\
\hline 30 & 35 & $15: 48$ & $\sqrt{ }$ & & 26 \\
\hline
\end{tabular}

Sumber : Pengumpulan Data

\section{Pengolahan Data}

Pengolahan data dilakukan untuk pengujian dan perhitungan yang dilakukan pada data sehingga menghasilkan informasi yang berguna untuk di analisa. Data-data tersebut ialah datadata yang berhubungan dengan permasalahan yang ditemukan oleh penganyam atap daun nipah di Desa Pulau Palas Kecamatan Tembilahan Hulu Kabupaten Indragiri Hilir yang menjadi objek penelitian. Data tersebut di dapat melalui survey lapangan dan penelitian langsung yang dilakukan oleh peneliti. Menghasilkan penelitian yang ilmiah dan bisa dipertanggung jawabkan, data yang dikumpulkan harus benar-benar rill dan bukan rekayasa.

Setelah melakukan pengamatan selama dua hari secara berturut-turut, data tersebut kemudian diolah menjadi sebagai berikut :

1. Lokasi Penelitian

Penelitian ini dilakukan di UKM Pak Andi di Desa Pulau Palas Kecamatan Tembilahan Hulu Kabupaten Indragiri Hilir.

\section{Interval Waktu Pengamatan}

Interval waktu pengamatan terhadap penganyam atap yang dilakukan adalah sebesar 11 menit dan 12 menit.

\section{Waktu Pengamatan}

Waktu pengamatan dilakukan selama satu bulan sebelum perancangan dan satu bulan setelah perancangan, yaitu pada hari selasa dan rabu, pada pelaksanaannya peneliti mengamati selama 7 jam yang dimulai dari pukul 8:00 16:00 WIB.

Berikut adalah jumlah bilangan random maksimal :

1. Bilangan Random Maksimal

Bilangan random maksimal diperoleh dari perhitungan sebagai berikut :

a. Bulan Pertama $: \frac{60}{11} \times 210 \mathrm{Jam}=1145$

b. Bulan Kedua $: \frac{60}{12} \times 210 \mathrm{Jam}=1050$

Frekuensi pengamatan selama dua hari dapat dilihat pada tabel 4.3

Tabel 4.3 Frekuensi Pengamatan

\begin{tabular}{|l|c|c|c|}
\hline Kegiatan & \multicolumn{2}{|l|}{$\begin{array}{l}\text { Frekuensi } \\
\text { Pengamatan } \\
\text { Hari Ke }\end{array}$} & \multirow{2}{*}{ Jumlah } \\
\cline { 2 - 3 } & 1 & 2 & \\
\hline Produktif & 28 & 29 & 57 \\
\hline Idle & 2 & 1 & 3 \\
\hline $\begin{array}{l}\text { Jumlah } \\
\text { Pengamatan }\end{array}$ & 30 & 30 & 60 \\
\hline OIU & 749 & 718 & 1.467 \\
\hline
\end{tabular}

Sumber : Pengumpulan Data

\section{Uji Keseragaman Data}

Uji keseragaman data dilakukan untuk mengetahui apakah data yang dikumpulkan telah seragam atau belum. Keseragaman data ditandai dengan tidak adanya data yang out of control. Uji keseragaman data dilakukan pada tingkat keyakinan $68 \%$ dan tingkat ketilitian $5 \%$. Ini berarti bahwa tingkat ketelitian yang menunjukan penyimpangan maksimal dari hasil pengukran sebesar 5\%. Berdasarkan pengamatan peneliti lakukan, maka dapat dilakukan uji keseragaman data sebagai berikut

1. Presentasi Kegiatan Produktif

Adapun kegiatan produktif pertama dapat diperoleh dengan menggunakan persamaan 2.1 sebagai berikut : 


$$
\begin{aligned}
\mathrm{P}_{1} & =\frac{28}{30} \\
& =0.93
\end{aligned}
$$

Untuk menghitung kegiatan produktif kedua dapat diperoleh dengan menggunakan Persamaan 2.1 sebagai berikut :

$$
\mathrm{P}_{2}=\frac{29}{30}=0.96
$$

2. Persentasi Terjadinya Kejadian RataRata

Setelah mendapatkan persentasi kegiatan produktif, maka selanjutnya dapat dicari persentasi terjadinya kejadian rata-rata dengan menggunakan Persamaan 2.2 sebagai berikut :

$$
\bar{p} \quad=\frac{0.93+0.96}{2}=0.94
$$

\section{Batas Kontrol}

Batas kontrol terbagi menjadi Batas Kontrol Atas (BKA) dan Batas Kontrol Bawah (BKB). Untuk menghitung BKA dan BKB dengan menggunakan Persamaan 2.3 dan 2.4 sebagai berikut :

Batas Kontrol Atas (BKA)

$$
\begin{array}{ll}
= & 0,94+2 \frac{\sqrt{0,94(1-\overline{0,94)}}}{60} \\
= & 0,94+2(0,03065) \\
= & 1,001 \\
& \text { Batas Kontrol Bawah (BKB) } \\
= & 0,94-2 \frac{\sqrt{0,94(1-0,94)}}{60} \\
= & 0,94-2(0,03065) \\
= & 0,878
\end{array}
$$

\section{Uji Kecukupan Data}

Banyaknya pengamatan yang dilakukan dalam work sampling dipengaruhi oleh dua faktor yaitu tingkat ketelitian dan tingkat kepercayaan dari hasil pengamatan. Uji kecukupan data dilakukan pada tingkat $68 \%$ dan tingkat ketelitian yang dikehendaki $5 \%$. Uji kecukupan data dilakukan untuk mengetahui apakah data yang telah dikumpulkan telah mencukupi atau belum.
Dimana jika $\mathrm{N}^{\prime} \leq \mathrm{N}$ maka data telah mencukupi dan pengamatan dihentikan. Namun jika $N^{\prime} \geq N$ maka data belum mencukupi dan pengamatan haus dilanjutkan hingga data mencukupi.

Karena data yang dikumpulkan telah seragam, selanjutnya dilakukan uji kecukupan data dengan menggunakan Persamaan 2.5 .

Dimana :

$\mathrm{N}^{\prime}=$ Jumlah pengamatan yang diperlukan

$\mathrm{k}=$ Harga indeks yang besarnya tergantung dari tingkat kepercayaan yang diambil

$\mathrm{s}=$ Tingkat ketelitian yang dikehendaki (bentuk desimal)

$\bar{p}=$ Produktivitas rata-rata pekerja (bentuk

desimal)

$$
\begin{aligned}
N^{\prime} & =\frac{1^{2}(1-0,94)}{(0,05)^{2}(0,94)} \\
& =51
\end{aligned}
$$

Dengan demikian maka data yang diperoleh dinyatakan cukup karena $\mathrm{N}^{\prime} \leq \mathrm{N}$.

\section{Ratio Delay}

Perhitungan ratio delay digunakan untuk mengetahui kinerja operator dalam melakukan suatu pekerjaan, berapa banyak waktu kerja operator tersebut dalam keadaan menganggur (idle). Adapun perhitungannya menggunakan persamaan 2.6 sebagai berikut :

$$
\begin{aligned}
\text { Ratio delay } & =\frac{5 \%}{68 \%} \\
& =0,07
\end{aligned}
$$

\section{Persentasi Produktif}

Untuk mengetahui persentasi produktif, maka dilakukan perhitungan dengan Persamaan 2.7 sebagai berikut :

$$
\begin{aligned}
\text { Persentasi produktif }= & \frac{57}{60} \times 100 \% \\
& =\quad 95 \% \\
& =\quad 0,95
\end{aligned}
$$

\section{Waktu Baku}

Berdasarkan data pengamatan diatas, dapat diperoleh waktu baku sebagai berikut :

1. Persentasi Produktif $=95 \%$

2. Jumlah Menit Produksi (JMP) 
Untuk menghitung Jumlah Menit Produksi (JMP) dapat menggunakan Persamaan 2.8 sebagai berikut :

$$
\mathrm{JMP}=0,95 \times 840=798 \text { menit }
$$

3. Waktu Yang Diperlukan Per Unit (T)

Setelah mendapatkan nilai jumlah menit produksi (JMP), selanjutnya dapat mencari nilai dari waktu yang diperlukan per unit dengan menggunakan Persamaan 2.9.

$$
\mathrm{T}=\frac{798}{1467}=4 \text { menit } / \text { keping. }
$$

4. Untuk menghitung nilai dari faktor penyesuaian waktu normal dengan metode westinghouse system adalah sebagai berikut :
a. Skill
$=\quad+0,08$
b. Effort
$=\quad+0,02$
c. Condition
$=\quad+0,00$
d. Consistency
Total

$$
\begin{array}{ll}
= & +0,01+ \\
= & +0,11
\end{array}
$$
Jadi P

$$
\begin{array}{ll}
= & (1+0,11) \\
= & 1,11
\end{array}
$$

Untuk menghitung waktu normal dapat menggunakan Persamaan 2.11 sebagai berikut : $\begin{array}{rll}\text { Waktu Normal } & = & 0,54 \times 1,11 \\ & = & 5 \text { menit } / \text { keping. }\end{array}$

5. Waktu Baku

$$
=5 \text { menit } / \text { keping. }
$$

Sebelum menghitung waktu baku, terlebih dahulu harus menghitung nilai kelonggaran (allowance), ditentukan berdasarkan faktor-faktor yang berpengaruh seperti yang diamati berikut ini :
a. Tenaga Yang Dikeluarkan $=12,00 \%$
b. Sikap Kerja = $4,5 \%$
c. Gerakan Kerja $=\quad 1,3 \%$
d. Kelelahan Mata $=0 \%$
e. Keadaan Temperatur Tempat Kerja $=\quad 5,50 \%$

f. Keadaan Atmosfer $=0,5 \%$

g. Keadaan tingkungan Yang Baik = $2,50 \%$ + Jumlah 26,3\%

Setelah melakukan perhitungan nilai kelonggaran (allowance), maka peneliti melanjutkan untuk menghitung waktu baku sebagai berikut :

$\begin{array}{rll}\mathrm{Wb} & =0,599+(0,599 \times 0,263) \\ & =6 \text { menit } / \text { keping. }\end{array}$

\section{Kesimpulan}

Dari hasil analsis dan pembahasan tentang Tingkat Produktivitas Pekerja Penganyam atap daun nipah Kelapa Dengan Menggunakan Metode Work Sampling. Maka dapat diambil kesimpulan sebagai berikut :

1. Work Sampling adalah suatu teknik untuk mengadakan sejumlah besar pengamatan terhadap aktivitas kinerja dari mesin, proses atau pekerja/operator. Pengukuran kerja dengan cara ini juga diklarifiksikan sebagai pengukuran kerja secara langsung. Karena pelaksanaan kegiatan pengukuran harus dilakukan secara langsung ditempat kerja yang diteliti.

2. Pengamatan tingkat produktivitas kerja menggunkan metode work sampling, dimana pengamatan dilakukan secara langsung terhadap pekerja penganyam atap daun nipah selama dua bulan yaitu sebulan data sebelum perancangan dan data sesudah perancangan system kerja, masing-masing selama 7 jam . Data-data dikumpulkan kemudian dianalisa dengan bilangan random sebelas dan dua belas menggunakan metode westinghouse dan tingkat kepercayaan $68 \%$ dan tingkat ketelitian 5\%. Dan diperoleh nilai waktu baku, waktu normal dan kelonggaran.

3. Berdasarkan hasil pemeltian,pekerja penganyam atap daun nipah bekerja dengan produktif dengan hasil $95 \%$ dan ratio delay sebesar $0,07 \%$. Hal ini menunjukan bahwa selama dilakukan pengamatan, pekerja menganggur atau melakukan pekerjaan lain hanya sedikit atau pekerja lebih banyak melakukan pekerjaan produktif.

4. Kelonggaran pada pekerja penganyam atap daun nipah diberikan adalah sebesar 23,6\% dengan rincian sebagai berikut : tenaga yang dikeluarkan Sebesar 12,00\%, sikap kerja sebesar 4,5\%, gerakan kerja sebesar $1,3 \%$, kelelahan mata sebesar $0 \%$, keadaan temperatur tempat kerja sebesar 5,50\%, keadaan atmosfer sebesar 0,5\%, dan keadaan lingkungan yang baik sebesar $2,50 \%$. 
DAFTAR PUSTAKA

Andi Wasono. 2017 Rangkuman dari Kebosanan Kerja. Karya Tulis. Jakarta Anitawidanti, Hafni. 2010. Analisis Hubungan Antara Stres Kerja Dengan Kepuasan Kerja Karyawan Berdasarkan Gender. Fakultas Ekonomi Universitas Diponegoro. Semarang.

Deviyanti, Sri. 2008. Studi Perbandingan Sistem Kerja Statis Dengan Rolling Tugas Operator Pada Unit Pengepakan Terhadap Peningkatan Output Produksi di PT.ISM Bogasari Flour Mills Surabaya. Teknik Industri UNIPRA. Surabaya.

Ida Kristina 2012. Pengaruh Lingkungan Kerja Terhadap Produktivitas Melalui Kepuasan Kerja (Kasus: Karyawan Usaha Mikro, Kecil Dan Menengah).

Skripsi.Temanggung. Definisi Lingkungan Kerja

Muchlis Riadi 2014. Definisi Lingkungan Kerja Kajian Pustaka. Jakarta.

Melayu S.P Hasibuan. 1996 Dasar Peningkatan Produktivitas Bumi Aksara Putra, Jakarta.

Mangkunegara, Anwar Prabu.2005. Evaluasi

Kinerja SDM. Refika Aditama.

Bandung.
Nurmianto, Eko. Ergonomi: Konsep Dasar dan Aplikasinya. Surabaya: Teknik IndustriITS.2008.

Ngizuddin, R. 2015. Analisa Pengaruh Suhu dan Kebisingan Terhadap Kelelahan Fisik laki-laki dan perempuan (Kasus: Lab. Ergonomi FST UIN Sunan Kalijaga). Skripsi, Jogjakarta.

Oktaria, Yudit. 2009. Telaah Kebosanan Kerja Karyawan Pabrik SSP II Unit Peleburan PT. KS dan Cara Untuk Mengatasinya. Fakultas Psikologi Universitas Gunadarma. Jakarta.

Sutalaksana, Iftikar Z. Teknik Tata Cara Kerja. Bandung: Institut Teknologi Bandung. 1979.

Siti Rahmawati.2008. Analisis Stres Kerja Karyawan pada PT Bank Rakyat Indonesia (Persero) Tbk Cabang Bogor. Departemen Manajemen, Fakultas Ekonomi dan Manajemen. Hal : 120121.

Thackray, Richard. 1981. The Stress of Boredom and Monotony: A Consideration of The Evidence. Phychosomatic Medicine, Vol. 43, No. 2 